\title{
MODERN SLAVERY: \\ STATE-INDUCED FORCED LABOUR IN MYANMAR (BURMA) \\ AND REACTIONS FROM THE INTERNATIONAL \\ COMMUNITY
}

\author{
Sheila M. Arianayagam and Jatswan S. Sidhu
}

\begin{abstract}
While human rights conditions began sharply deteriorating in Myanmar with the inception of military rule in 1962, however, it was not until 1988 that the international community began seriously taking notice of these abuses. The brutal crackdown of peaceful demonstrations in that year coupled with the excessive use of force by the country's ruling military thus placed Myanmar on radar international community. Apart from human rights abuses in general, one that has received considerable attention from the international community is the issue of state-induced forced labour - a modern form of slavery. Although this practice dates back to 1962, however, it was not until 1997 that the problem attracted international attention. The aim of this article is therefore to examine the conscription of state-induced forced labour in Myanmar and analyse reactions from the international community, namely like-minded states and international organisations. Although state-induced forced labour was utilised for both military and non-military purposes, this article will however, concentrate on the latter, as it was mainly aimed at overcoming the woes of a cash-strapped military junta. In addition, the article only covers the period till early 2011 as the practice was not only initiated but even perpetuated by the country's ruling military junta.
\end{abstract}

Keywords: Myanmar; military rule; modern slavery; state-induced forced labour; international community.

\section{INTRODUCTION}

Although the issue pertaining to the rampant use of state-induced forced labour in Myanmar first appeared on the international agenda in early 1997, however, the practice had been widespread since 1962 when the country's military usurped power from a democratically elected government. In fact, the brutal crackdown of peaceful pro-democracy demonstrations in 1988 by the military was a major event that placed Myanmar on the radar of like-minded states, international organisations and transnational advocacy networks (TANs). While incidents of human rights abuses, including forced labour, remained undocumented till 1988, mainly due to Myanmar's policy of self-imposed isolation, nonetheless, after 1988 voluminous information began surfacing on the litany of human rights abuses inflicted by the country's military junta on its people. The use of forced labour by the state in Myanmar is in fact very much linked to the abandonment socialism in 1988 when the country's military junta began opening its doors to foreign investments. Faced with diminishing 
state financial resources, on the one hand, and Western sanctions, on the other, the junta therefore resorted to the widespread and systematic use of forced labour as a means to develop the country's extremely backward infrastructure, mainly aimed at luring foreign investors from countries that were willing to do business with it. The practice continued unabated till 1999 when the International Labour Organization (ILO) passed a resolution not only strongly condemning the practice in Myanmar but even barred the country from receiving aid from the body and attending its meetings. This act of 'de facto expulsion' of the country finally led the junta to cooperate with the ILO, aimed at eventually eradicating the practice. In March 2011, a nominally civilian government - mostly comprising of former military men - took over the reins of power from the military junta and gave an undertaking to the ILO that it would eradicate the menace by 2015 . Nevertheless and in spite of the said undertaking, a recent report reveled that there are currently 384,037 people categorised as forced labourers in the country, with Myanmar ranking $42^{\text {nd }}$ out of the 162 countries in the 2013 Global Slavery Index. ${ }^{1}$

\section{STATE-INDUCED FORCED LABOUR IN MYANMAR}

According to Article 2(1) of the ILO Convention (No. 29) concerning Forced or Compulsory Labour, forced labour is defined as "all work or service that is exacted from any person under the menace of any penalty and for which the said person has not offered voluntarily."2

In Myanmar, the use of state-induced forced labour began with the inception of military rule in 1962 and remains a problem till the present. The practice has affected millions of people across the country, especially in the ethnic minority areas and has resulted in the disintegration of families and communities, the destruction of homes and villages, displacement and even the loss many innocent lives. In fact, it was imposed by the military junta on its citizens from all strata of society, including children and the elderly. It was due to the widespread of this menace that in 2005 the ILO described the country as a "tragic case study in which the state, in particular, the military, can perpetrate forced labour with impunity."3

The procurement of forced labour in Myanmar can in fact be traced back to the Village Act (1908) and the Towns Act (1907) that were enforced during the British colonial period. Nevertheless, provisions in these enactments only authorised the use of unpaid workers solely for community benefits. ${ }^{4}$ However, the military junta reinterpreted and abused these laws to their own benefit such that it was used to enrich themselves, their families and cronies. Under military rule (March 1962-March 2011), labourers were forcibly conscripted, denied wages and faced various forms of abuses. They were often brutally victimized, both physically and emotionally, where beatings and torture were routine, with women constantly facing the horrors of rape. ${ }^{5}$ Coupled with this were the harsh working conditions, fatigue and sicknesses which resulted in countless deaths. The elderly, frail and those attempting to elude working orders were mercilessly killed by the military. In addition, village heads were tortured and killed if they failed to fulfill the quota on the number of labourers and porters to be supplied to the military. ${ }^{6}$

The practice that was initially procured for small scale work around the villages was later employed for major projects worth billions of dollars. For instance, 
from 1968 until 1969, the junta compelled the people to clear a piece of land which was the site for the construction of the Lawpita dam. ${ }^{7}$ Since 1980 , civilians were also ordered to make fences for the pylons on an annual basis. ${ }^{8}$ However, the brutal suppression of the 1988 demonstrations resulted in the international community severing all aid, except that for humanitarian purposes. Therefore, in order to increase cash flow into the country, the junta began initiating business deals with various multinational corporations (MNCs) and foreign governments willing to work with it. This proved detrimental to the people's well-being as the junta procured forced labour to complete most projects initiated through joint ventures with the foreign investors. As a matter of fact, state-induced forced labour in Myanmar was used for both military and non-military purposes during this period. For military purpose, forced labour was frequently used for portering and building military camps, to name a few, while for non-military purpose, the key sectors where the junta conscripted forced labour were in industries such as logging, mining, garment, agriculture, tourism and oil and gas.

\section{Forced Labour in the Logging Industry}

Timber was one of the many commodities that were harvested by the junta due to its high monetary returns. The vast areas of Myanmar's virgin forests are rich in various types of exotic and expensive wood, including teak. Myanmar is one of the only four countries in the world that have an abundant supply of this precious timber, and in 1994, it accounted for 80 percent of the world's teak supply. ${ }^{9}$ As such, ethnic minority areas became the focus of the junta as large pockets of teak trees were mostly in the Karen and Karreni states, with these minorities largely conscripted forcibly to work in the industry. ${ }^{10}$

Thus, by the early 1990s, teak was the second highest revenue source for the junta. Realising the potential income of the logging industry, the junta converted extensive forest areas into commercial plantations. In other words, Myanmar's forests were ravaged indiscriminately in the name of 'development'. 'The logging industry, as all other industries in Myanmar, was, at least till 2011, controlled by the junta or companies directly linked to it. For instance, the Myanmar Timber Enterprise (MTE) which controls all timber trade in the country was closely linked to high ranking military officials. Besides this, the private sector was also involved in the teak and timber trade through partnerships with the junta. In 1997, the State Law and Order Restoration Council's (SLORC) Minister for Forestry stated that "Burma's teak forests would be logged to increase economic development with support from the private sector."12

However, working conditions in the industry were atrocious and the practices inhumane. People were forcibly conscripted to fell logs, transport it out of the forest, clear land for the commencement of road building projects and undertake road maintenance activities. Villagers were also compelled to replant trees, and especially teak. For instance, in the Pekhon Township (Shan State), villagers had to plant more than a million trees, of which 20 acres were to be planted with teak. Forced labourers were not paid, brought their own food and work tools, and faced severe punishment if work orders were ignored or if they were unable to fulfill the required quota of logs for the day. Forced labourers who were unable to achieve the targeted amount of felled logs were forced to purchase timber from outside sources at exorbitant prices. 
In fact, in many instances these labourers were also forced to clear land and fell logs in areas covered with landmines. In doing so, the junta treated its people as replaceable commodities, totally disregarded their safety and compelled them to work in areas where fatalities or serious bodily injuries were most severe. As a result, many died due to freak accidents, such as being crushed by falling trees and timber. Besides this, the forced labourers also had to work around military camps, in addition to portering for the soldiers. ${ }^{13}$

\section{Forced Labour in the Mining Industry}

Apart from logging, mining for rubies, jade and other precious stones was another economic activity that witnessed high instances of state-induced forced labour in Myanmar. In fact, Myanmar's imperial green jade is of superior quality and worth millions of dollars due to its high demand throughout the world. Since the 1960s, it had been under the tight grip of the junta, through its Ministry of Mines. One source reveals that "from mining, to cutting, polishing, trading and selling, the junta's generals control the gem industry with a vice-like grip."14 On the extreme harsh conditions in the sector another source noted that "the country's mining industry is built on suffering: forced and child labour, land confiscation, drug abuse, sexual exploitation and environmental damage." ${ }^{15}$ Although bulldozers and water cannons were used in excavating the precious stones, back-breaking manual labour was also needed to collect the precious stones from the depth of the mines. ${ }^{16}$

One such case was in Hpakant (Kachin State), where thousands of villagers were forced to mine jade in state-owned mining companies. ${ }^{17}$ Besides rubies and jade, gold was also mined by using forced labour. In fact, the country's 1994 law governing gold mining simply failed to uphold human and workers rights by ignoring high incidences of forced labour in the industry, which in turn, only benefited the mining companies, foreign investors and the junta. In fact, it was mainly due to the high incidences of state-induced forced labour that the cost of mining gold in Myanmar was around 20 percent lower when compared to other countries. Ivanhoe, a Canadianbased company, was amongst the major investor in gold mining, securing eight out of the 16 concessions offered to foreign companies. ${ }^{18}$

\section{Forced Labour in the Garment Industry}

Faced with economic sanctions imposed by the West, Myanmar's military junta also began focusing on the garment industry as a major source of revenue. In fact, a 1997 source revealed that "Myanmar has sought to position itself as a destination for foreign garment manufacturers." $"$ As such, the country became a prime destination for designers and apparel companies, mainly due to its abundant supply of cheap labour.

In this sector, people were forcibly conscripted to build factories and work in these industrial units mushrooming throughout Myanmar. The 2003 United States (US) State Department report on human rights in Myanmar revealed that "forced labor, including child labor, has contributed materially to the construction of industrial parks subsequently used largely to produce manufactured exports including garment. ${ }^{20}$ In addition, forced labour was also used in constructing roads and other infrastructure necessary to transport apparel. 
As for wages, labourers were paid a mere four US cents per hour and forced to labour continuously and at a fast pace in order to meet the large quantity needed for the export market. In fact, most of these garment factories operated round the clock for seven days. There were also instances where labourers were required to clock in 60 hours per week and denied a decent wage. ${ }^{21}$ In other instances, labourers were compelled to give half their pay back to the employers, and those who complained were intimidated by army personnel. ${ }^{22}$ Taking stock of the scenario, one source even labeled this practice as "the worst sort of labour exploitation - it is the height of irresponsibility." 23

\section{Forced Labour in the Plantation Sector}

Investigations by the Karen National Union (KNU) and the Free Burma Coalition (FBC) revealed that state-induced forced labour was also widely used in the oil palm plantations. In February 1999, some 400,000 acres between Kauthuang and Myeik in the Tanintharyi Division were earmarked for said purposes. Subsequently, in 2001, other locations were also cleared for the opening-up of palm oil plantations. This frequently involved demanding and exhausting work, as villagers were compelled to clear designated areas and plant the saplings. ${ }^{24}$

In December 2005, the junta also started the cultivation of castor oil plants and jatropha, mainly as a substitute for diesel. ${ }^{25}$ Following this, in 2006, the junta implemented a ten-year project to grow castor oil plants, with each township required to plant 40 acres. As such, villagers were forcibly conscripted to clear areas, plant, attend and collect the seeds. ${ }^{26}$ Additionally, the junta delivered an edict ordering the planting of jatropha in eight million acres of land, with each state in the country allocating some 500,000 acres for this purpose. In fact, in Yangon Division alone, some 20 percent of its fertile land was apportioned for the cultivation of jatropha. Beginning in 2006, the junta compelled all civilians into clearing the designated areas and planting jatropha. Each household had to send a family member to work in the plantations and faced retribution if the orders were ignored. Consequently, if the quota for the number of plants that should be grown was not fulfilled, or if the crops were damaged or if the people were caught condemning the junta's agenda, the villagers were, either fined, arrested and/or threatened with a death sentence. In addition, villagers were also instructed to clear land for the building of a jatropha oil factory and oil refining facilities. ${ }^{27}$

\section{Forced Labour in the Tourism Sector}

Tourism was another sector that was viewed by the military junta as having great potential in increasing the country's revenues, in addition to providing the junta with a guise of legitimacy for their rule. By declaring 1996 as 'Visit Myanmar Year', the junta began undertaking efforts at beautifying the country and constructing modern facilities in anticipation of the thousands of tourists expected to visit the country. This inadvertently led to a sharp increase in state-induced forced labour statistics in the country. ${ }^{28}$

The people were forcibly conscripted to work on several tourism development projects such as rebuilding and restoring the adjacent area of Mandalay's Golden Palace. ${ }^{29}$ For example, to clean the moat around the Mandalay Palace alone, some 
20,000 villagers were conscripted. By using forced labour, the junta also began constructing buildings to house many religious and historic artifacts. One such instance was in 1994, where forced labour was conscripted to construct a Buddha Museum in Sittwe (Rakhine State). However and as a result of the horrific working conditions, the project infamously came to be known as 'dukkha Museum' or the ' museum of suffering, ${ }^{30}$

Other projects included the construction of a dam at the tourist site of the Inle Lake (Shan State), the construction of a railway line in the vicinity of Pagan and modernising airports. ${ }^{31}$ For instance, between 1992 and 1994, almost 200,000 people were forcibly conscripted to build an international airport at Bassein (Ayeyarwaddy Division). In addition, villagers were also forced to work on road improvement projects such as the Yangon-Bago (Pegu) highway, Kengtung-Tachilek road in the Shan State and the construction of a new ring road in Mandalay. Once an area had been designated as a tourist attraction, people living the vicinity were not only relocated but even conscripted to construct roads and other facilities for the convenience of foreign tourists. An example of this is the road linking the Nga Saw beach in the Ayeyarwaddy Delta to the Bassein River. In fact, even hotels, mainly owned by family members of the junta officials and their cronies, were also constructed partly using forced labourers. ${ }^{32}$

\section{Forced Labour in the Oil and Natural Gas Industry}

In terms of lucrative revenues going into the coffers of the junta, the oil and natural gas sector was considered the most important industry in Myanmar. In fact, even before the onset of economic sanctions by the US, Canada and the European Union (EU) in 1997, the country had managed to attract numerous foreign companies that invested millions of dollars in order to receive lucrative oil and gas contracts. Once an agreement had been signed between the MNC and the junta, villagers were relocated and forced to work to clear the area, build roads, work on the construction of pipelines as well as provide security along the pipeline route. ${ }^{33}$

Among the many investment projects in the country, the construction of the infamous Yadana and Yetagun pipelines, were the most substantial as these were the largest and most profitable single projects in the country. ${ }^{34}$ However, in the process of construction, Unocal (USA), Chevron (US), Premier Oil (United Kingdom) and Total (France) were also partly, together with the junta, responsible for the most horrific human rights abuses in Myanmar, especially the widespread use of forced labour. The people in this region were forcibly conscripted to not only work on the project site, but also construct other facilities in the vicinity. For instance, they were forced to build roads and helipads for the business community to visit the site and even constructed camps and barracks for the use of the soldiers. In addition, the labourers were also tasked to guard the pipeline routes from attacks or sabotage by insurgent groups. $^{35}$

For example, in 2000, forced labour and forced portering were procured for the construction of the Kanbauk-Myaing Kalay gas pipeline. In this case, villagers were forcibly conscripted to clear the area, dig trenches for the construction of the pipeline, construct and repair roads, work on the project site itself and perform duties as sentry in the area. In addition, they were also required to work in the military 
camps that were set up along the route and carry loads of supplies for the soldiers. ${ }^{36}$ Another large scale project was the Burma-China pipeline financed by the Chinese, South Korean and Indian MNCs, in partnership with the Myanmar Oil and Gas Enterprise (MOGE). This involved the Shwe gas project and the Burma-China oil transport project. In fact, investigations by the EarthRights International (ERI) confirmed the countless instances of forced labour in the construction of these pipelines. $^{37}$

Besides this, villagers, including expecting women and children, were procured as porters, frequently forced to carry heavy loads for the military. They were not only abused if they were slow but even beaten senselessly if they were unable to continue the journey. In fact, very frequently medical treatment was withheld, the terminally ill left behind and those who attempt to escape were executed. The duration of forced portering was indefinite. Porters faced food scarcity and exhaustion, while female porters were often raped by military personnel. In addition, the junta also used the villagers, including children, as human minesweepers to clear areas with landmines. ${ }^{38}$

\section{REACTIONS FROM THE INTERNATIONAL COMMUNITY}

Reactions and responses from the international community on the issue of the Myanmar's junta's blatant violations of human rights in general and, state-induced forced labour in particular, have been, at the very best, mixed. These can be divided into two broad categories namely the reaction from like-minded states and international organisations and non like-minded states. The first category represents states/international organisations that have not only strongly condemned human rights abuses in Myanmar but have even taken strong measures to address the issue while second category represents those parties that have connived with the Myanmar junta and held an indifference attitude towards human rights abuses in the country. While the former category includes the ILO, US, EU, Canada, Japan and Australia, the latter comprises mainly of China, India and the ASEAN member states. Adamantly holding to their principle of non-interference in the internal affairs of Myanmar, the latter has preferred to engage the junta through economic activities. In fact, these were the countries that signed numerous economic agreements, which saw them profiting from the joint ventures with the Myanmar junta.

While the ILO has remained in the forefront by taking the Myanmar junta to task over its failure to comply with international labour standards, the approaches from like-minded states too have been varied. Generally speaking, these responses can be divided into two main categories. The first category are countries/international organisations such as the ILO, US, Canada and the EU that used censures and sanctions as a preferred method to deal with the junta's obstinacy in not adhering to international law and norms, including international labour laws. The second category comprises countries such as Japan and Australia. While stressing on the importance of good human rights practices and democracy, these countries did not believe in the enforcement and efficacy of sanctions. Rather they preferred a cordial and professional discussion and discourse to finding a solution to the imminent problems pertaining to human rights abuses in Myanmar. Last but least, are the transnational advocacy networks (TANs) that were also actively involved in attempting to reverse the human rights and labour situation in Myanmar. In fact, it is the TANs that have 
played a crucial role in keeping the issue of state-induced forced labour on the agenda of like-minded states and international organisations.

\section{The International Labour Organization (ILO)}

The ILO had been actively pursuing the issue of state-induced forced labour in Myanmar since the 1960 s by frequently calling on the country's military junta to repeal the Towns and Village Act as these acts were used by the latter to legalise their procurement of forced labour. Although similar calls were also made in the 1970s and 1980s, they had been simply ignored by the Myanmar junta. One of the major setbacks to the ILO's earlier efforts pertained to the availability of documented evidence which only began surfacing in the 1990s. The issue of forced labour in Myanmar reappeared onto the ILO's agenda in 1997 following a series of complaints by the International Confederation of Free Trade Unions (ICFTU). However, the initial response of the Myanmar junta was one of outright denial. Further afield, the junta even argued that the people were not forced but were voluntarily contributing their labour. They based their arguments on the Buddhist religion, customs and traditions such that the country's Foreign Minister, Ohn Gyaw, was quoted in 1996 as saying that "whatever we do in this life without any remuneration would result in merit in the next life." 39

In fact, initially, the junta not only failed to undertake measures to eradicate forced labour but instead increased its procurement. Meanwhile, the ILO, together with other human rights bodies and countries supporting the organisation's efforts, continued with their own investigations into the occurrences of state-induced forced labour in the various parts of Myanmar. The debates and discussions on this issue between the junta and the organisation finally climaxed with the formation of an ILO Commission of Inquiry in 1996. This eventually resulted in a detailed report by the ILO on stated-induced forced labour in Myanmar, published in 1998. The report reveled that that regardless of the junta's claims that forced labour did not exist in Myanmar, there was "abundant evidence before the Commission showing the pervasive use of forced labour imposed on the civilian population throughout Myanmar by the authorities...". ${ }^{40}$ Despite the revelation, the junta was not perturbed by the Commission's report. Therefore, on 17 June 1999, the ILO took the drastic action of imposing a ban on all aid and technical assistance to the country, in addition to barring it from attending all ILO activities and meetings until all its demands were met - a move that was viewed as the de facto expulsion of Myanmar from the ILO. Further and due to the junta's lax attitude, in 2000, the ILO finally invoked Article 33 against Myanmar - being the first time in the history of the ILO - where the ILO's Governing Body asked International Labour Conference (ILC) to take appropriate measures to end the use of forced labour in Myanmar. According to the US Deputy Labour Secretary, Andrew Samet, the decision reflected "the more than three decades of frustration with the Burmese junta on their failure to stop the use of forced labour a practice that is abhorrent to this organisation." 41

As a piecemeal gesture, the Myanmar junta had earlier, in March 1999, issued SPDC Order No. 1/99 which outlawed forced labour in the country - although it was hardly enforced. However, sensing that the ILO was about to enforce further stringent measures, in October 2000, the junta issued another Supplementary Order to Order 1/99 that reinforced the outlawing of forced labour in the country. All the same it also 
decided allow the visit of the ILO Technical Cooperation Mission, and later, the ILO High Level Team into the country, both in 2001. Further, in March 2002, the junta also agreed to accept an ILO Permanent Representative in Yangon to directly and personally handle the issue and implement a Plan of Action to eradicate forced labour. Whilst on the one hand the junta continued its engagement with the ILO, on the other, it simply failed to undertake concrete measures at eradicating forced labour. In addition, the ILO also could not get the junta to agree to the setting up of a complaints mechanism for forced labour victims to seek legal avenues. As such and in view of the worsening forced labour crisis in the country, the ILO then announced that it would be taking the issue to the United Nations Security Council (UNSC).

As a result, Myanmar finally agreed to the ILO's demands and a Complaints Mechanism was established in February 2007, through the signing of a Supplementary Understanding between the Myanmar junta and the ILO. ${ }^{42}$ The understanding was to be renewed on a yearly basis. The ILO's persistence and perseverance finally saw the new nominally civilian government, elected during the November 2010 elections, signing a Memorandum of Understanding (MOU) with the organisation agreeing to eradicate forced labour by 2015. This was a significant step as the new administration has given a time-frame to end the practice. According to the current ILO Liaison Officer, Steve Marshal: ${ }^{43}$

First is that we have moved completely away from the previous mode, and that is a very important step, where it is now accepted that it has been and continues to be a problem which must be addressed. The government now has entered into a major action plan to address all of the different forms of forced labour...

Besides the ILO, the issue of forced labour has also been discussed annually at the UNGA with body not only strongly condemning the practice but even frequently calling on the Myanmar junta to eradicate the problem. Apart from the UNGA, the issue has also received considerable attention from the United Nations Commission on Human Rights (UNCHR) and since March 2006, the UN Human Rights Council (UNHRC). In addition to the ILO, both these bodies have also conducted their own investigations into the problem of state-induced forced labour in Myanmar and even monitor the issue very closely.

\section{The United States (US)}

One of the strongest proponents for sanctions against the junta, the objective of the US was not to engage the junta but rather to call for its international isolation. As a measure to circumvent the deteriorating human rights conditions in Myanmar, the US implemented a series of economic and diplomatic sanctions against the junta from 1988 until at least 2010. In aftermath of the bloody crackdown by the Myanmar junta on peaceful demonstrations, in September 1988, the US imposed an arms embargo, terminated all aid and discontinued the General System of Preferences (GSP) privileges it had earlier accorded to country. In addition, it also ended investment facilitation through the Overseas Private Investment Corporation, Export-Import Bank assistance, and placed restrictions on the imports of oil and gas. ${ }^{44}$ Aside from this, the 
US also pressured the International Monetary Fund (IMF) and the World Bank to cease all aid to Myanmar. ${ }^{45}$

Due to the sharp increase in forced labour statistics in Myanmar in the 1990s, the US adopted a far more stringent policy against the junta. In 1997, President Bill Clinton classified Myanmar as a "national emergency" following the junta's repressive policies and declared the country as "an unusual and extraordinary threat to the national security and foreign policy of the United States." ${ }^{\circ 6}$ Following this, Clinton also enforced a new law barring all new investments into Myanmar. Aside from the litany of human rights abuses, the decision was also partly influenced by the widespread and rampant use of forced labour. In presenting the new bill to the US Senate, the representatives declared that the ban would be enforced until the President was satisfied with the efforts undertaken by the junta to improve the country's abysmal human rights record. As such, the junta was required to provide concrete proof of their efforts in eradicating forced labour from the country.

In June 2000, when the ILO called on its member states to review their relations with Myanmar, the US in turn, introduced a legislation to impose an import ban on Myanmar. Further, in 2003, the US enforced the Burmese Freedom and Democracy Act (BFDA), which ultimately banned all imports from Myanmar. ${ }^{47}$ In addition, all assets of the junta officials, either in the government or financial and banking sectors placed in the US were frozen as per Section One of the BFDA, which became a law through Executive Order $13310 .^{48}$ This law was renewed annually by the US Senate Finance Committee due to the continuation of human rights violations in Myanmar, including forced labour. Further afield and as a result of the litany of human rights violations in the mining sector, in July 2008, the US President signed a new law, the Tom Lantos Block Burmese JADE (Junta's Anti-Democratic Efforts), which collectively banned the import of jade and rubies from Myanmar, and imposed certain criterias on these items from other countries. This law came into effect through amendments to the BFDA in $2003 .{ }^{49}$

In further striving to eradicate forced labour and other human rights violations from Myanmar, the US introduced the selective purchasing method, thus being the first country to do so. Subsequently, four states and 30 municipalities around the US launched boycott campaigns against the Myanmar junta. In the state of New York, by May 1997, there were 14 cities that had implemented this measure. The US had also attempted to bring the issue of ongoing human rights violations in Myanmar to the attention of the UNSC, albeit little success. Among the topics that the US wanted to discuss was the junta's lukewarm response to the ILO. The attempt to take the issue to the UNSC mainly failed due to the veto exercised by both China and Russia. ${ }^{50}$

\section{The European Union (EU)}

Following the violent crackdown of the 1988 demonstrations, the EU terminated all aid, discontinued defense cooperation, suspended high level official visits to Myanmar and imposed an arms embargo on the country. In addition, the EU also constantly attempted to compel the junta to eradicate forced labour in Myanmar, at every opportunity presented to it. 
Subsequent to the worsening forced labour crisis in the country, especially following the announcement of the Visit Myanmar Year in 1996, the EU launched an aggressive campaign against the junta. These efforts eventually resulted in the termination of Myanmar's GSP trade privileges with the EU in 1997. Earlier, the EU had also enforced a Common Position against Myanmar in 1996, which allowed the group as a collective body, and member states, to impose sanctions against the country. Such a law allowed Britain to unilaterally launch a campaign targeting British companies that maintained trade links with Myanmar. Hereinafter, Britain successfully managed to persuade eighteen companies, including Premier Oil and British American Tobacco, to disinvest from Myanmar.

However, as forced labour continued unabatedly, the EU consistently strengthened its sanctions against the junta in 2000, 2003 and 2004. The junta's continued procurement of forced labour was even discussed at the United Nations Economic and Social Council (ECOSOC) session in 2006 at the behest of the Director General of the ILO. The Finish representative to the UN conveyed the EU's concern over the deteriorating labour situation in Myanmar. While acknowledging the junta's attempts to undertake certain reforms to improve labour standards, it was however hoped that these reforms would be put into practice and not remain purely rhetoric. The delegate further noted that there were also attempts by the Myanmar junta to suppress the voices of justice as forced labour victims who endeavored to seek legal redress were instead prosecuted. The EU denounced these attempts of harassing the victims and called for the practice to be halted immediately. ${ }^{51}$

\section{Canada}

Canada had also implemented various measures against the Myanmar junta in its efforts to eradicate the latter's labour practices. Following the 1988 demonstrations, Canada terminated all aid, suspended trade promotions and military sales, severed all commercial package deals, imposed a visa ban on all of the junta's top officials, and severed diplomatic ties with Myanmar. Although Canada had initially attempted to approach the issue through its constructive engagement policy, however, this proved futile. As a result, in 1997, Canada implemented limited punitive measures or Selective Economic Measures due to the worsening human rights situation in the country, including forced labour. ${ }^{52}$ Under this scheme, Canada abolished the General Preferential Tariff (GPT) accorded to Myanmar for its agricultural and industrial products and included the country into the Area Control List, which required Canadian companies to apply for export permits in order to export any products into Myanmar. This was followed by a 2003 policy which removed Myanmar from the Least Developed Country (LDC) Market Access list that accorded certain privileges on import of goods. ${ }^{53}$ In 2007, Canada implemented yet another set of sanctions against the junta namely the Special Economic Measures (Burma) Regulations. With this new law, Canada banned all imports and exports to and from Myanmar, banned all new investments by Canadian companies, froze assets of Myanmar nationals in Canada, halted all financial services to and from Myanmar, barred Canadian registered ships or aircrafts from docking or landing in Myanmar and vice versa, and banned the export of all technical data from Canada into Myanmar. ${ }^{54}$

\section{Japan and Australia}


As a result of the junta's brutal crackdown of the 1988 demonstrations, Japan suspended all aid and postponed further economic assistance to the country. However, in February 1989, Japan was also the first country to recognise the State Law and Order Restoration Council (SLORC). Subsequently and although Japan disallowed the signing of any new aid policies, it nevertheless recommenced the distribution of aid on a case-by-case basis under existing agreements and enforced new stringent guidelines on its Official Development Assistance (ODA) to Myanmar in 1991. In spite of this, however, over the years Japan continued to provide monetary aid, especially for humanitarian purposes. ${ }^{55}$

Besides concentrating on economic issues, Japan also attempted to influence the junta on other issues, such as persuading it to accept the proposal of stationing an ILO permanent representative in Myanmar. The Japanese rational was based on the fact that such a move would not only improve junta's international image but would also reflect the latter's seriousness in wanting to eradicate forced labour from the country. ${ }^{56}$

Similarly, Australia imposed a ban on all development aid, official travel and financial sectors in 1990, following concerns over the country's poor human rights record. However, at the same time, Australia also began to engage the Myanmar junta on certain issues, including welcoming the presence of Myanmar officials at the ASEAN Regional Forum (ARF) summit held in Australia in 1999. In addition, it also held four introductory training schemes focusing on 'Human Rights and Responsibilities in Myanmar' from September until October 2001 in Yangon and Mandalay. These were aimed at educating Myanmar officials, mainly security personnel, on international human rights standards. Further human rights training schemes for Myanmar's government officials were also held from 2002 until 2003 with the support of the ILO. ${ }^{57}$ However, these schemes were eventually halted following the 2003 Depayin incident, when Aung San Suu Kyi was rearrested.

\section{Transnational Advocacy Networks (TNAs)}

With the onset of blatant human rights abuses in Myanmar in 1988 in general, and forced labour in particular, most TNAs worldwide began actively pursuing campaigns to dissuade the business community and certain countries from maintaining economic relations with the country's junta. The TNAs began using a variety of means and approaches to highlight the growing number of state-induced forced labour cases in Myanmar. These included the strategy of shaming companies doing business with Myanmar, launching boycott campaigns for their products, calling on them to disinvest and petitioning shareholders to pressure these companies to disinvest, to name a few. To kick start the campaign, the US-based Free Burma Coalition (FBC) started the 'Free Burma Campaign' in the early 1990s. With the specific aim of turning 'Burma into the South Africa of the 1990s,' the TNAs argued that the inflow of foreign investments only served to shore-up a brutal regime and thus made the possibility of regime change extremely remote. However, the TNAs also encountered numerous problems in achieving their objectives as their detractors used various tactics to ensure their economic activities were not jeopardised by the sanctions imposed by the Western nations. 
For instance, the continued demand for teak and other types of hardwood from Myanmar remained high, with Asian countries clamoring to obtain logging concessions. The business community in most countries, including Western, used specific methods to bypass the sanctions. Improper administration of label rules and other weaknesses were among the loopholes which the business community used to their advantage. When timber from Myanmar was used to create furniture in Thailand, the business community listed the product as made in Thailand, with the source country, Myanmar, remained hidden. Hence, the products were able to be brought undetected into countries which had prohibited exports from Myanmar, such as the US. Most of the timber was sold to the US as finished or manufactured products, and the origins of the raw materials were listed as 'plantation' for teak, and from 'other Southeast Asian countries' for other types of hardwood. ${ }^{58}$ The United Kingdom (UK) Timber Trade Federation, in 2007, admitted that most of the teak products sold in the UK were listed as originating from 'Thailand', although the raw material was obtained from Myanmar. In fact, teak from Myanmar had been used to manufacture furniture located in many UK's leading parks and for the manufacturing of yachts, furniture and other common products. ${ }^{59}$ The other prime purchasers of Myanmar's timber in Europe were the Scandinavian countries. Several of the industrialists from these countries used teak from Myanmar not only for domestic consumption, but also provided it to retail groups around the US and throughout Europe. Their tagline was that these sales assisted Myanmar in achieving 'economic development' ${ }^{60}$

Even precious stones were sold openly in the international market without fear of reprisal. Despite the numerous laws implemented by the like-minded states to cripple Myanmar's mining industry, a covert operation by an NGO had unearthed evidence of rubies being marketed in an open and brazen manner, and where most of the buyers were from China, Thailand and Singapore. In addition, private sales were arranged for buyers who were willing to pay inflated prices for specific gems. It was reported that the Myanmar Gems Enterprise had earned approximately $£ 400$ million from these auctions.

The same scenario existed in the garment sector, where among the many foreign companies taking advantage of the low production cost in Myanmar were the US-based companies. In fact, in the mid-1990s, 82 percent of the total US imports from Myanmar were garments. ${ }^{61}$ While in 1995 , the US apparel import was at $\$ 65.1$ million, a year later, in 1996, it had increased to $\$ 89.7$ million. ${ }^{62}$ According to the US embassy in Myanmar, there were around 1,000 factories in the country that hired approximately 500,000 forced labourers, with most these factories owned by investors from Hong Kong, South Korea and Taiwan. ${ }^{63}$ This is because Myanmar not only offered cheap labour but even low production cost. However, according to the FBC's Director of Policy and Strategy, Aung Din, "when you buy something labeled 'Made in Burma', you help perpetuate widespread forced labor in the country.",64

Following the revelation by the US-based Institute for Global Labour and Human Rights (IGLHR) in the early 1990s that certain garments by the famous designer, Polo Ralph Lauren, were manufactured in Myanmar using forced labourers, who were paid a mere six cents per hour, activists in the US launched an aggressive campaign to dissuade retailers from continuing their economic relationship with the Myanmar junta. Spearheaded by the FBC, a 'Boycott Burma campaign' was launched in the US that eventually spread to other parts of Europe and even Australia. Besides 
Polo Ralph Lauren, a number of other Western-based apparel companies also had business links with the Myanmar junta. As a result of the numerous campaigns by these TNAs, a number of companies eventually withdrew from Myanmar. These include Levi Strauss (1992), Liz Claiborne (1994), Disney, Macy's (1995), Eddi Bauer (1995), Columbia Sportwear (1996), London Fog Industries (1996), Oshkosh B' Gosh Inc. (1996) J. Crew (1997), Polo Ralph Lauren (1997), Kenneth Cole (2000), Jansport (2000) and United States Army and Air Force Exchange (2000). ${ }^{65}$ On its decision to disinvest from Myanmar in 1992, a Levi's spokesman was quoted as saying that "under current circumstances it is not possible to do business in Burma without directly supporting the military government and its pervasive violations of human rights."66

In October 1997, the IGLHR, in collaboration with the TNAs and some influential individuals launched the 'National Day of Conscience to End Sweatshops'. In addition, the IGLHR also coordinated a 'Holiday Season of Conscience', and proposed to reveal the names of the thirty companies who were the worst violators of human rights in Myanmar. ${ }^{67}$ The successes in persuading apparel companies to withdraw from Myanmar eventually resulted in a 27 percent drop in the US garment imports from Myanmar. ${ }^{68}$ In addition, the IGLHR also sent out petitions to companies such as Warner Bros., Kohl's, Adidas and Nautica, calling on them to disinvest Myanmar. As a result of the pressure and exposé by these TNAs, Adidas immediately issued a statement denying IGLHR's claim that it was obtaining goods from Myanmar, and insisted that the pictures of 'Adidas - made in Burma labels' revealed by the IGLHR as evidence were either previous editions or fakes. ${ }^{69}$

In Myanmar's tourism sector and in view of the large scale procurement of forced labour, Aung San Suu Kyi and the National League of Democracy (NLD) as well as the US-based National Coalition Government of the Union of Burma (NCGUB) began calling on tourists to refrain from visiting Myanmar. In Suu Kyi's words, "Burma will be here for many years, so tell your friends to visit us later. Visiting now is tantamount to condoning the junta."70 With regards to the Visit Myanmar Year 1996, Suu Kyi renamed it as 'Don't Visit Burma Year'. Furthermore, tourists were only allowed to visit certain places. Areas of contention were off-limits to tourists, as was contact between these foreigners and the locals. In 2001, a decree was issued by the Myanmar Tourism Promotion Board (MTPB) prohibiting “ unnecessary contact" between tourists and citizens of the country under the semblance of safeguarding the welfare of the tourists. ${ }^{71}$

However, regardless of these calls and campaigns, tour operators still promoted Myanmar as a prime tourist destination. For example, Lonely Planet persisted in promoting Myanmar as part of their tour package regardless of the many campaigns launched against it. ${ }^{72}$ Nevertheless, there were certain companies that adhered to advice from the TNAs. For example, Orient Express removed its segment on Myanmar as a tourist destination following a meeting with representatives from the certain TNAs. ${ }^{73}$

The TNAs also targeted the oil and natural gas companies by using several methods. They reached out to the shareholders in the hope that they would be able to pressure their directors to reject having business dealings with the junta. For instance, the shareholders of Unocal Corporation, who had received credible reports of forced 
labour in the construction of the pipelines in Myanmar, held a proxy vote to decide if there had been a serious breach of labour rights in the company's involvement in the oil and gas industry in Myanmar. ${ }^{74}$ The Burma Forum of Los Angeles (BFLA), with the support from the Los Angeles Federation of Labour, also held a demonstration to coincide with Unocal's annual meeting in May 2000, with another held in May 2003. ${ }^{75}$ Interfaith, the organisation that provided the necessary information to the shareholders of Unocal, was also responsible for calling and pressuring the company to withdraw of Myanmar. Shareholder resolutions were also filed against Amoco Corporation and Texaco Inc. These actions did prove successful on certain occasions, such as when Amoco Corporation withdrew from Myanmar in 1994, only two years after it had invested in the country. However, in other instances, the gesture remained symbolic. Nevertheless, it highlighted the growing awareness of people around the world regarding the issue of stated-induced forced labour that was being perpetrated by Myanmar's military junta.

In Europe, representatives were also sent to a shareholders meeting of IHC Caland, one of the prime investors in the oil and gas industry in Myanmar, to highlight the growing number of forced labour cases as a result of European investments in the country. As a result, a number of European companies too began disinvesting from Myanmar. These were namely Philips (1996), Carlsberg (1996), Heineken (1996), Interbrew (Labatt's) (1996), Burton (1997), British High Street (1997), Ericson (1998), to name a few.

In Canada, the Canadian Friends of Burma (CFOB) worked closely with Project Maje to target the board of directors of Canadian companies that maintained their business links with the junta, and those that intended to invest in Myanmar. As a result of this campaign some of the Canadian companies that disinvested from Myanmar were Petro Canada (1992), Bank of Nova Scotia (1995) and Seagram Co. Ltd. (1997). With a similar campaign launched in Australia, two Australian companies that eventually withdrew from Myanmar were the BHP Petroleum Australia and Student Travel Association (STA). All in all and as a result of the FBC' s 'Boycott Burma Campaign', some 56 companies, mainly Western, disinvested from Myanmar between 1992 and 2000.

\section{CONCLUSION}

Although the problem of forced labour continues to persist in Myanmar, nonetheless, the country's newly-elected nominally civilian government has promised to completely eradicate the menace by 2015 . In fact, the country is currently working closely with the ILO to achieve the said objective. Nevertheless, the continuation of international pressure is critical towards ensuring that the new government complies with international standards and laws pertaining to good labour practices and undertakes measures to completely eradicate forced labour from Myanmar sooner than later. In the event pressure is prematurely halted, the situation may become precarious as the new government may not be motivated to realise these necessary changes. 


\section{NOTES}

${ }^{1}$ The Global Slavery Index 2013, Dalkeith, Western Australia: Walk Free Foundation, 2013, pp. 7-8.

${ }^{2}$ Forced Labour Convention, 1930 (No. 29), Geneva: International Labour Organization (ILO), <http://www.ilo.org/dyn/normlex/en/f?p=NORMLEXPUB:12100:0::NO::P12100_ILO_COD $\mathrm{E}: \mathrm{C} 029>$

${ }^{3}$ Chronic Emergency: Health and Human Rights in Eastern Burma, Thailand: Back Pack Health Worker Team (BPHWT), 2006, p. 56.

${ }^{4}$ Santipap, "The Junta and the ILO: Is It Time for the tiger to finally bare its teeth?," Burma Issues, Vol. 16, No. 6, August 2006, <http://www.burmalibrary.org/docs13/BI-200608(Vol.16-08).pdf>

${ }^{5}$ Capitalizing on Conflict: How Logging and Mining Contribute to Environmental Destruction in Burma, Chiang Mai, Thailand: EarthRights International (ERI), October 2003, p. 18.

${ }^{6}$ K. S. Venkateswaran, Burma beyond the Law, London: Article 19, August 1996, pp. 49-50.

${ }^{7}$ Dammed by Burma's Generals: The Karenni Experience with Hydropower Development from Lawpita to the Salween, Bangkok: Karenni Development Research Group (KDRG), 2006, pp. 27-49.

${ }^{8}$ Gaining Ground: Earth Rights Abuses in Burma Exposed, Chiang Mai: ERI, 2008, pp. 84, 89 \& 90-91.

${ }^{9}$ Bruce E. Johansen, "Burma (Myanmar): Forced Labor in the World's Last Teak Forest,"

Indigenous People and Environmental Issues: An Encyclopedia, 2003,

$<$ http://www.ratical.com/ratville/IPEIE/Burma.html>

10 "Forced Labour," Dublin: Burma Action Ireland (BAI), $<$ http://www.burmaactionireland.org/forc.html>

${ }^{11}$ Tim Keating, Teak is Torture: Forced-Labor Logging in Burma, New York: Rainforest Relief, June 1997, p. 3.

${ }^{12}$ Johansen, "Burma (Myanmar)."

${ }^{13}$ A Conflict of Interests: The Uncertain future of Burma's Forests, London: Global Witness, October 2003, p. 54.

${ }^{14}$ Rajeshree Sisodia, "Burma's bloody trade," New Statesman, 27 October 2008.

${ }^{15}$ Ibid.

${ }^{16}$ Dan Mcdougall, "The curse of the blood rubies: Inside Burma's brutal gem trade," Mail Online, 18 September 2010.

${ }^{17}$ Rajeshree Sisodia, "Jade trade in Myanmar thrives on exploitation, rights abuses," The National, 29 September 2008.

${ }^{18}$ Charles Large, "Gold Diggers: Big companies push small prospectors aside in hunt for Burma's riches," The Irrawaddy, Vol. 13, No. 10, October 2005, http://www2.irrawaddy.org/print_article.php?art_id=5082>

19 "Ralph Lauren producing in Burma," Online Burma Library, 25 June 1997, <http://www.burmalibrary.org/reg.burma/archives/199706/msg00415.html>

20 "Country Reports on Human Rights Practices, 2003 - Burma," Washington D.C.: Bureau of Democracy, Human Rights \& Labor, U.S. Department of State, 25 February 2004, $<$ http://www.state.gov/j/drl/rls/hrrpt/2003/27765.htm>

21 "Propping up the dictators in Burma," Pittsburgh, PA: Institute for Global Labour and Human Rights (IGLHR), 1 March 2001, $<$ http://www.globallabourrights.org/reports?id=0266>

${ }^{22}$ Triumph International Supports Burma's Military Dictatorship, London: Burma Campaign UK (BCUK), 30 November 2001, p. 3.

${ }^{23}$ Barnes, "Burma ties under fire."

${ }^{24}$ World Rainforest Movement (WRM), "Burma: Forced labour in oil palm plantations," WRM Bulletin, No. 47, June 2001, <http://www.wrm.org.uy/oldsite/old-index.html> 
25 "Bio-fuels in Burma," Mae Sot, Thailand: Arakan Rivers Network (ARN), 2009, $<$ http://www.arakanrivers.net/?page_id=141>

${ }^{26}$ Saw Eh Na, "Burma Plants the Oil: A Further Demand for Slave Labour," Burma Issues, Vol. 16, No. 8, August 2006, p. 2.

${ }^{27}$ Biofuel by Decree: Unmasking Burma's bio-energy fiasco, Ethnic Community

Development Forum (ECDF), 2008, p. 1,

28 "Summary of Forced Labour in Burma," Karen Human Rights Group (KHRG), 7 August

1997, <http://www.burmalibrary.org/reg.burma/archives/199709/msg00120.html>

${ }^{29}$ Boycott Burma Holidays: How Tourism Benefits Burma's Dictators, London: BCUK, p. 2.

30 "Summary of Forced Labour in Burma."

31 "Tourism," London: BCUK, 2013,

$<$ http://www.burmacampaign.org.uk/www.burmacampaign.org.uk/aboutburma/tourism.html>

32 "Summary of Forced Labour in Burma."

${ }^{33}$ Zaw Oo (comp.), "TED Case Studies: Yadana Gas Pipeline in Burma,", Washington D.C.: Trade and Environmental Database (TED), American University, December 2000, $<$ http://www1.american.edu/ted/burma-pipe-conflict.htm>

${ }^{34}$ Tyler R. Giannini, Destructive Engagement: A Decade of Foreign Investment in Burma, Washington D.C.: ERI, 1999, p. 9.

${ }^{35}$ Fueling Abuse: Unocal, Premier and TotalFinaElf's Gas Pipelines in Burma, Washington D.C.: ERI, 2002, pp. 1-4.

${ }^{36}$ Laid Waste: Human Rights along the Kanbauk to Myaing Kalay gas pipeline, Bangkok: Human Rights Foundation of Monland (HURFOM), May 2009, p. 2.

${ }^{37}$ ERI, The Burma-China Pipelines: Human Rights Violations, Applicable Law, and Revenue Secrecy, Situation Briefer No. 1, March 2011, pp. 1-2 \& 6.

${ }^{38}$ Human Rights Yearbook (2002-03): Burma, Thailand: Human Rights Documentation Unit (HRDU), National Coalition Government of the Union of Burma (NCGUB), October 2003, $<$ http://www.ibiblio.org/obl/docs/Yearbook2002-3/yearbooks/Home\%20Page.htm>

${ }^{39}$ Human Rights Yearbook 2004: Burma - Forced Labour, HRDU, NCGUB: Thailand, August 2005,

<http://www.ibiblio.org/obl/docs3/Burma\%20Yearbook\%202004/HTML\%20Peages/Forced_ Labor.htm> See also, Frank Ching, "Burma wants to end its isolation," Far Eastern Economic Review (FEER), 15 August 1996, p. 36.

${ }^{40}$ Richard Horsey, Ending Forced Labour in Myanmar: Engaging a Pariah Junta, New York: Routledge, 2011, pp. 16-17 \& 23.

${ }^{41}$ Ed Shepherd (comp.), "Burma," Hong Kong: Asia Monitor Resource Centre (AMRC), 27 September 2007, <http://www.amrc.org.hk/text/alu_special/country_profile/burma> 42 "The International Labour Organization's Forced Labour Complaint Mechanism," Burma Issues Vol. 20, No. 7/8, July-August 2010, p. 4.

43 "Press Release: Reform Process in Myanmar is irreversible, says ILO expert," Geneva: ILO, 16 November 2012, <http://www.ilo.org/global/about-theilo/newsroom/news/WCMS_193299/lang--en/index.htm>

${ }^{44}$ Aung Zaw, "Sticks or Carrots," The Irrawaddy, Vol. 17, No. 5, August 2009, p. 7.

45 "US names "outposts of tyranny," The Age, 19 January 2005.

${ }^{46}$ A Threat to Peace: A Call for the UN Security Council to Act in Burma, New York: DLA Piper Rudnick Gary Cary, September 2005, p. 40.

${ }^{47}$ Burmese Freedom and Democracy Act of 2003, Public Law 108-61, Washington D.C: U.S. Department of Treasury, 28 July 2003, pp. 864-865.

48 "Executive Order 13310 of July 28, 2003: Blocking Property of the Government of Burma and Prohibiting Certain Transactions," Federal Register, Vol. 68, No. 146, 30 July 2003, pp. $44853 \& 44856$.

${ }^{49}$ Tom Lantos Block Burmese JADE (Junta's Anti-Democratic Efforts) Act of 2008, Public Law 110-286, Washington D.C.: U.S. Department of Treasury, 29 July 2008, p. 2638.

${ }^{50}$ Niksch, Burma-U.S. Relations, CRS Report for Congress, Washington D.C: Congressional Research Service (CRS), 4 October 2007, pp. 13-14. 
51 "EU Presidency Statement - ECOSOC Substantive Session: Situation in Myanmar Regarding Use of Forced Labour," Geneva: EU @ UN, 26 July 2006, <http://www.euun.europa.eu/articles/en/article_6150_en.htm>

52 "Canada's Official Policy on Burma," Ottawa: CFOB, 2013,

$<$ http://www.cfob.org/canPolicy/canPolicy.shtml>

${ }_{53}^{53}$ Sanctions: Special Report, Bangkok: ALTSEAN Burma, November 2003, p. 21.

54 "Notes for an address by the Honourable Maxime Bernier, Minister of Foreign Affairs, on the subject of Burma, to the Economic Club of Toronto," Ottawa: Foreign Affairs and International Trade Canada, 14 November 2007,

$<$ http://international.gc.ca/media/aff/speeches-

discours $/ 2007 / 385598$.aspx ?lang=eng\& view $=\mathrm{d}>$

${ }^{55}$ Sanctions: Special Report, p. 23.

${ }^{56}$ Development, Environment and Human Rights in Burma/Myanmar - Examining the Impact of ODA and Investments, Tokyo: Mekong Watch, Japan, 2001, p. 15.

${ }^{57}$ David Kinley and Trevor Wilson, "Engaging a Pariah Regime," Human Rights Quarterly, Vol. 29, 2007, p. 369.

${ }^{58}$ Country Facts, Issues for suppliers of forest products Burma (Myanmar), Washington D.C.: WWF Global Forest \& Trade Network (GFTN), 4 June 2004, p. 1.

59 "Burmese 'blood timber' used at leading UK parks, gardens and tourist attractions,"

Ecostrom, November 2007, <http://www.eco-storm.com/2007/11/burmese-blood-timber-

used-at-leading-uk-parks-gardens-and-tourist-attractions/>

${ }^{60}$ Johansen, "Burma (Myanmar)."

${ }^{61}$ "U.S. Companies Increase Use of Sweatshops in Burma," Pittsburgh: IGLHR, 22 June

2000, <http://www.globallabourrights.org/reports?id=0270>

62 "Ralph Lauren producing in Burma," Online Burma Library, 25 June 1997,

<http://www.burmalibrary.org/reg.burma/archives/199706/msg00415.html>

63 "Foreign Direct Investment and the Garment Industry in Burma," Burma Economic Watch, June 2001, <http://www.ibiblio.org/obl/docs/FDI_\&_Garments_Industry_in_Burma.htm>

${ }^{64}$ Dan Beeton, "Free Burma - No Dollars for Dictators," Nonviolent Activist, January-

February 2003, <http://www.warresisters.org/nva/nva0103-2.htm>

65 "Foreign companies withdrawn from Burma," The Irrawaddy, 1 January 2003,

$<\mathrm{http} / / / \mathrm{www}$ 2.irrawaddy.org/research_show.php?art_id=457>

${ }^{66}$ William Barnes, "Burma ties under fire," South China Morning Post, 11 July 2000,

$<$ http://www.burmalibrary.org/TinKyi/archives/2000-07/msg00011.html>

67 "Ralph Lauren producing in Burma."

${ }^{68}$ Free Burma Coalition (FBC), "May Dept. Stores "Makes the Right Choice", Joins Burma

Boycott," Online Burma Library, 28 March 2003,

$<$ http://six.pairlist.net/pipermail/burmanet/20030328/000123.html>

${ }^{69}$ Barnes, "Burma ties under fire."

${ }^{70}$ Boycott Burma Holidays, London: BCUK, p. 2.

${ }^{71}$ Ko Ko Thet, Responsible Tourism in Myanmar: Current Situation and Challenges, Prague: Burma Centre Prague, 2012, p.15.

72 "Burma and Lonely Planet: A personal look back," London: Tourism Concern, 28 March 2008, <http://www.tourismconcern.org.uk/index.php/news/28/154/Burma-and-Lonely-PlanetA-personal-look-back.html>

73 John Jackson, "Wish You Wouldn't Go There," The Irrawaddy, 1 March 1999,

$<$ http://www2.irrawaddy.org/article.php?art_id=1181>

${ }^{74}$ Karl Schoenberger, "The Human Rights Pipeline: Charges of Slave Labour in Myanmar Lead to Ballot at Unocal," Los Angeles Times, 11 April 1994.

75 "May 19 - Unocal Shareholder Meeting Demonstration: "Unocal Out of Burma," Palo

Alto, CA: Burmese American Democratic Alliance (BADA), 2003,

$<$ http://www.badasf.org/2003/2003-unocal-demo-brea.htm> 